\title{
Analysis of the economic feasibility of a mining project due to the presence of natural underground cavities
}

\author{
lure Borges de Moura Aquino \\ Mestre em Engenharia Mineral - PPGEM \\ Universidade Federal de Ouro Preto - UFOP, \\ Escola de Minas \\ Departamento de Engenharia de Minas \\ Ouro Preto - Minas Gerais - Brazil \\ iurebmaquino@gmail.com \\ Hernani Mota de Lima \\ Prof. Associado - \\ Universidade Federal de Ouro Preto - UFOP, \\ Escola de Minas - \\ Departamento de Engenharia de Minas \\ hernani.lima@ufop.br
}

\begin{abstract}
The legislation for the protection and conservation of caves is recent in Brazil. In 2008, the Decree 6.640 was enacted and in 2009, the Normative Instruction $\mathrm{N}^{\circ} 2$ by the Brazilian Environment Ministry (MMA, Portuguese acronyms) was published. Mining operations cause a significant impact on the caves when they are present in or next to the mineral body. The impacts include the suppression of cavities and impacts on physical and bio-speleological stability of the caves. On the other hand, the actual legislation causes a significant impact on the mineable reserves when cavities are present. This article aims to assess the impact of the natural cavities on the feasibility of a mining project, based on the federal legislation, as well as to propose alternatives to combine mining activity with cave protection. For this research, three scenarios of open pit for a hypothetical ore body were considered for the assessments. This paper presents the results achieved for the three and comments on the necessity of researches to conciliate the conservation of the natural underground cavities with the mining activities.
\end{abstract}

keywords: mining feasibility, speleology, mine planning, natural underground cavity legislation.

\section{Introduction}

Natural underground cavities or caves, as popularly known are hollow spaces in a rock mass formed by a type of geologic process (POULSON and WHITE, 1969, FORD, 1988; BRASIL,1990). Activities such as mining, directly interfere in the natural heritage and can also interfere in the cultural heritage, when they are destroyed and modify the ecosystem and archaeo-palaeontological sites. Caves along with the environment, are directly affected in these processes.

To promote sustainable development and mitigate the conflicts regarding the environment and the productive segment, many countries have defined

\section{Methodology}

For this study, a bibliographic review was necessary to contextualize environmental legislation about protection of cavities and all of the diverse rules and have established standards for operations that have an impact on the environment. The legislation that regulates the use and conservation of natural cavities is recent. The last published acts are Decree 6.640/2008 and the Normative Instruction Number 02 of the Brazilian Environment Ministry (Ministério de Meio Ambiente - MMA). These acts regulate the classification of the natural underground cavities in 4 degrees: Maximum, High, Medium, and Low Speleological Relevance, and define their protection radius.

Depending on the number of highly relevant caves present in the mining area, these cavities in some cases, can derail enterprises both in the initial installation phase and in the operating phase. Thus, the recent change in the Brazilian Speleological legislation, related to the lack of specific works that conciliate mining activities and preserve natural underground cavities, justifies a study about the economic impact of the new legislation on the mineable reserve and on alternative mining projects that guarantee the protection of cavities and enables the maximization of the use of mineral resources. The objective of this study is to evaluate the feasibility of a mining project in the presence of natural underground cavities. mining operations that directly impact these cavities. To achieve the proposed objectives, a case study was adopted. In the choice of this case, adopted as essential criteria were: the presence of natural underground cavities in the area, the existence of carbonate rock occurrence of economic interest, and 
the viability for the mining and commercialization of the mineral good.

The karstic region of Arcos-PaínsDoresópolis-Iguatema was chosen

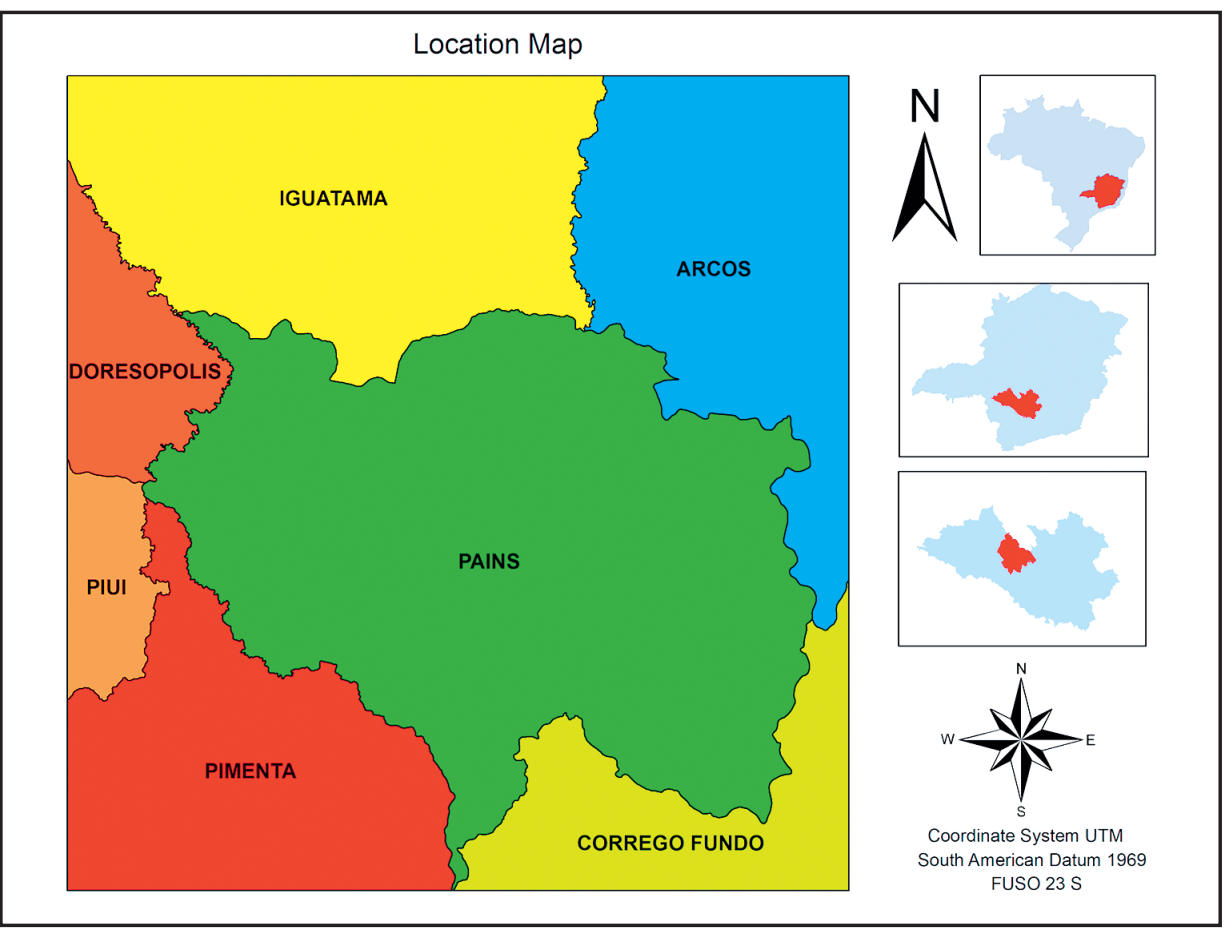

A study region was selected that contained natural cavities in accordance with data from the Environmental Impact Assessment and Environmental Impact Report (EIA and RIMA, Portuguese acronyms), available in the State Environment Foundation (FEAM,
Portuguese acronyms), and could be valued according to a level of relevance for each cavity. For this, Decree 6640/2008 and the IN 02/2009 of MMA were considered. A speleological zoning was established, dividing the areas into high, medium, or low speleological relevance because it met the established criteria (Figure 1).
Figure 1

Location of the area of study

zones, which enabled the delimitation of influential areas. Based on a typical stratigraphy column for the region and its topography, a hypothetical ore body was created. The mineable reserve or body estimated for this body is $65.4 \mathrm{Mt}$ of limestone (Figure 2).

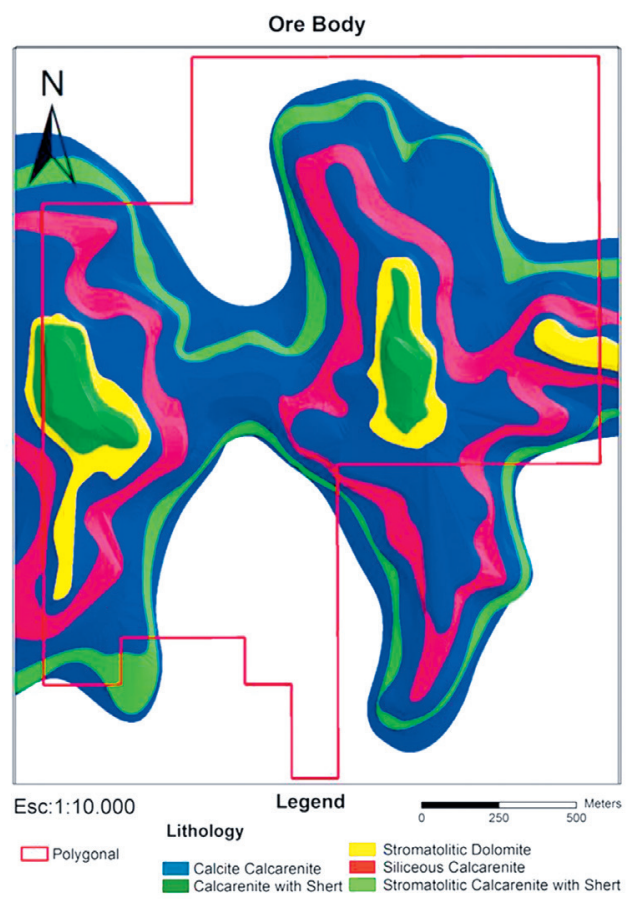

From this deposit, and applying the speleological zoning, three open pit mines were prepared considering three different scenarios (Table 1).
Thus, the proposed scenarios differ in the open pit dimensions and in the mineable reserve estimate. For each scenario, an Economic Exploitation
Figure 2

Hypothetical ore body

Plan was elaborated based on the estimated mineable reserve and its economic viability. 


\begin{tabular}{|c|c|c|}
\hline & Scenarios & Characteristics \\
\hline & Scenario 1 & $\begin{array}{l}\text { Maintaining the cavities' protection radius of } 250 \mathrm{~m} \text {. } \\
\text { Suppression of the cavities of high, medium and low speleological relevance. } \\
\text { Environment Compensation } \\
\text { No open pit limit restriction. }\end{array}$ \\
\hline & Scenario 2 & $\begin{array}{l}\text { Maintaining the cavities' protection radius of } 250 \mathrm{~m} \text {. } \\
\text { No suppression of cavities } \\
\text { No invasion of cavities' area of influence. } \\
\text { No environment compensation } \\
\text { Open pits limits restricted to low speleological potential areas. }\end{array}$ \\
\hline $\begin{array}{r}\text { Table } 1 \\
\text { Definition of scenarios }\end{array}$ & Scenario 3 & $\begin{array}{l}\text { Adoption of a } 100 \text { m protection radium for cavities of médium speleological rel- } \\
\text { evance } \\
\text { No suppression of cavities } \\
\text { No invasion of cavities' area of influence. } \\
\text { No environmental compensation } \\
\text { Open pit limits restricted to low speleological potential areas. } \\
\text { Implementation of monitoring cavities' physical and biospeloelogical integrity } \\
\text { program }\end{array}$ \\
\hline
\end{tabular}

To mount the database, to define the areas for speleological zoning, and to analyze economic viability, different software was used. Among them were: ArcView 9.3 for digital mapping, GIS for

\subsection{Protection Legislation}

The most recent legislative acts concerning the protection of the national speleological heritage collection are: Decree 6.640 (2008) and the Environment Ministry Normative Instruction Number 2 (2009) (BRASIL, 2008 and 2009). The current law establishes the criteria for establishing the valuation according to several factors that are decisive for whether to allow or not the realization of any irreversible interference in the cavity; in other words, the suppression of this cave. According to the legislation, the cavities are classified in 4 degrees of speleological relevance (Maximum, High, Medium and base editing, final map layouts, integrated georeferenced information analysis, interpretation of regional images, area and distance calculations, DWG and DXF editing and treatment of pre-existent data,

Low). For each relevance degree a measure of protection or compensation is adopted.

The natural cavities classified as maximum speleological relevance are the only cavities that aren't inclined to be targeted by any impact. This is the only type of cavity that can completely derail a mining project depending on some variables, such as the positioning of it within the ore body being considered. The cavities classified as high speleological relevance can be suppressed if two cavities with the same characteristics are preserved, and if there aren't two cavities around, the governmental organ will be in charge of proposing
AutoCad 2008 for topography confection, Google Earth for providing aerial images, and Micromine 11.01 for the activities of drawings of open pits and estimation of mineable fields.

other compensatory measures. In the case of cavities classified as medium speleological relevance, the responsible organ should provide a financial compensation. For the cavities of low relevance, no compensatory measure is necessary.

The legislation also sets the influence radius (or a protection radius) for a cavity as being the horizontal projection of the outer contour of the cavity plus the minimum of $250 \mathrm{~m}$. The protection radius helps to protect the cavity and its surrounding, as the external area has a direct influence on the events and interactions that occur within the cave's environment.

also of secondary data collected in the CECAV database (Figure 3).
Figure 3

Cavities present in the area of study, special attention to the DNPM polygon. tified in the surrounding area of this study. These data are from surveys of primary data executed in the area, and

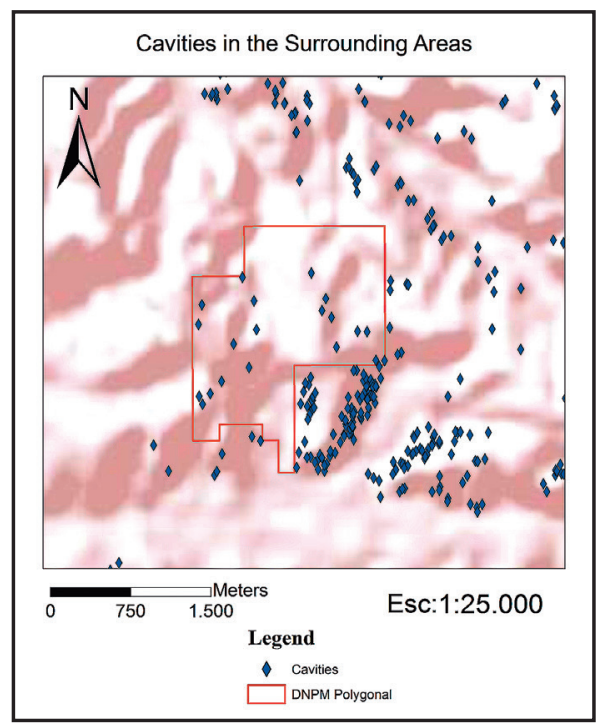


The cavities present inside and around as far as 250 meters away from the polygon DNPM were valued according to the presence or absence of attributes regulated by the Normative Instruction 02/2009, of the Environment Ministry, in accordance with article 5 of Decree 99556/1990, amended by Decree 6640/2008. These studies revealed the presence of 5 high relevance cavities, 14 medium relevance and 48 low relevance cavities.

After performing the valuation of the cavities, it was possible to determine the speleological zoning that aims to define areas of maximum, high, medium or low speleological relevance in function of the cavities' areas of

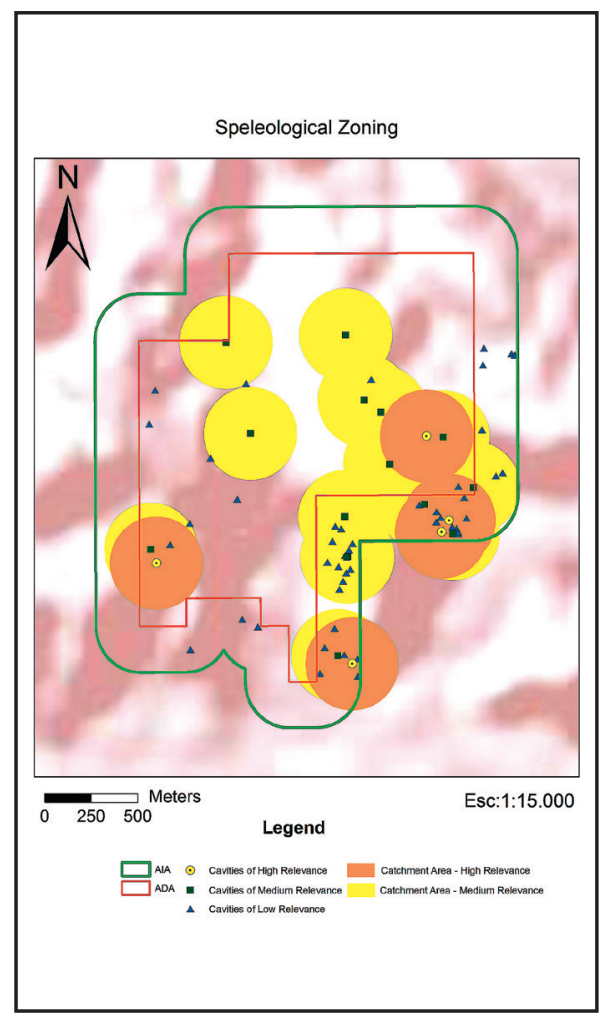

\subsection{Mine Planning and Definition of Pit Boundaries}

The mine planning, more precisely the pit boundaries and other installations, should respect the environmental and geometrical restrictions of the field, and also the technical and operational constraints for full development of the mine. En-

\subsection{Scenario 1}

The pit boundaries for Scenario 1 are restricted only to the polygon DNPM, and the geology of the body and all of the cavities present in the

\subsection{Scenario 2}

The pit boundaries for Scenario 2 are restricted to only those zones that are away from the influence of high and medium speleological relevance

\subsection{Scenario 3}

The pit limits for Scenario 3 are included in new areas of low speleological potential, established in the speleological vironmental restriction imposed by the cavities is an extremely important factor and should be evaluated with caution. The pit boundaries were established based on the influence areas of the cavities present in the area. With the aid of Micromine software,

area are subject to suppression. Thus, there are no restrictions regarding the pit boundaries due to the cavities. The total estimated mineable reserve

cavities, and the restrictions due to the geographic limits of the polygon DNPM and ore body geometry. The total estimated mineable reserve for

zoning assuming a $100 \mathrm{~m}$ influence radius for medium relevance cavities. The total mineable reserve for Scenario 3 was 27 influence present there. The influence area of a cavity was established by a radius of 250 meters from the outer contour of its horizontal projection, as defined in the IBAMA Ordinance Number 887/1990, CONAMA Resolution Number 347/2004 and reaffirmed in Annex II of IN 02/2009 of MMA (Figure 4).

Figure 4

Speleological Zoning for the area of study

based on the speleological zoning and on the orebody geometry, an open pit was designed for each proposed scenario. With the pit projects designed, it was possible to estimate the mineable reserve for each scenario and, consequently, evaluate its feasibility.

for Scenario 1 is $49.1 \mathrm{Mt}$ of ore $(75 \%$ of the total reserve), 34.2 Mt of waste and a stripping ratio of 0.7:1 (Figure 5 , left).

Scenario 2 was $3.8 \mathrm{Mt}$ of ore $(06 \%$ of the total reserve), $8.4 \mathrm{Mt}$ of waste and a stripping ratio of 2.3:1 (Figure 5 , center).

Mt of ore (41\% of the total reserve), 21.3 Mt of waste and a stripping ratio of 0.79:1 (Figure 05, right). 

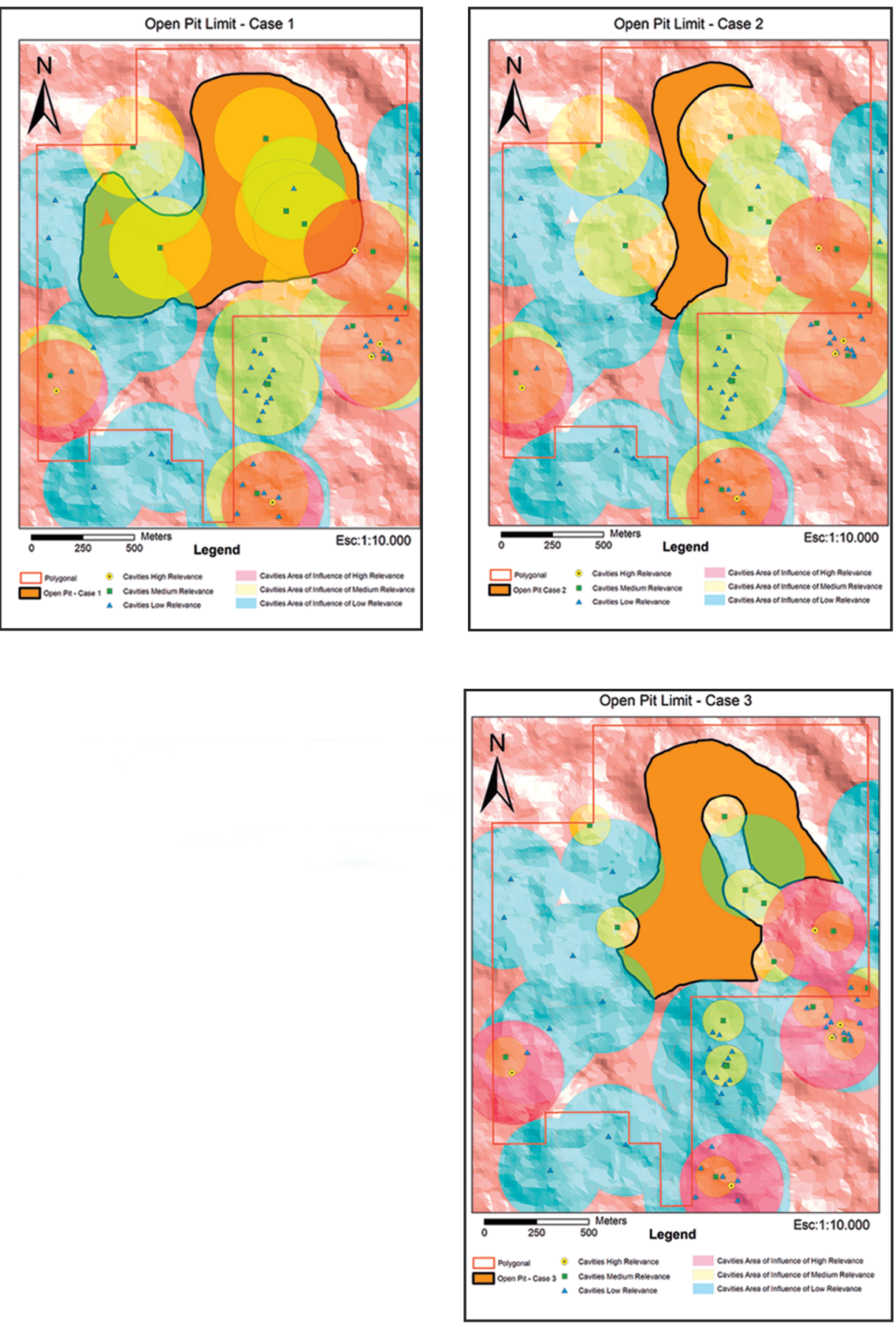

\section{Results}

An economic exploiting plan was prepared for each proposed scenario based on the calculation of its mineable reserve, on its given investment costs (CAPEX) and its operational costs (OPEX), which allowed a further economic viability analysis for each case, based on a development with a monthly output of $120,000 \mathrm{t}$, an estimated recovery of $90 \%$, and the selling price of the product equal to $\mathrm{R} \$ 30.00 /$ ton. These figures were compiled from various Economic Exploitation Plan (PAE) private companies, according to HARTMAN, (1992 and 2002) and HUSTRULID and KUCHTA, (1979).

CAPEX involves all infrastructure investments, and improvements needed for the installation of the mining operation. For this study the investments
Figure 5

Pit Boundaries for Scenario 1 (left), Scenario 2 (rigth) and Scenario 3 (below).

amounted to $\mathrm{R} \$ 6,890,000,00$ and are the same for the three scenarios. These costs are listed in Table 2. OPEX involves all the costs inherent to the operation (i.e. production costs). In the three scenarios, the same configuration is used for the workforce, equipment fleet and expenses with the unit and auxiliary operations. Operating costs are listed in Table 3 (AQUINO, 2014). 
Table 2 CAPEX

\begin{tabular}{c|c} 
Investment Type & Cost (Brazilian Real) \\
\hline Pre-operational investments & $125,000.00$ \\
\hline Plant Processing & $100,000.00$ \\
\hline Equipment, Machinery and Vehicles & $2,500,000.00$ \\
\hline Working capital & $3,665,000.00$ \\
\hline Environmental Compensation - Suppression Cavities* & $500,000.00$ \\
\hline * Only in Scenario 01 & $250,000.00$
\end{tabular}

\begin{tabular}{|c|c|c|}
\hline Personal Cost & Quantity & Cost (Brazilian Real) \\
\hline Higher Level & 01 & $8,430.98 /$ month \\
\hline Technical level & 07 & $2,975.64 /$ month \\
\hline Operational Level 3 & 13 & $2,479.70 /$ month \\
\hline Operational Level 2 & 11 & $1,938.76 /$ month \\
\hline Operational Level 1 & 06 & $1,487.82 /$ month \\
\hline Operational Cost & & - \\
\hline Stripping & & $4.80 / \mathrm{t}$ \\
\hline Drilling & & $2.5 / \mathrm{t}$ \\
\hline Explosives & & $3.6 / \mathrm{t}$ \\
\hline Loading/Transport & & $4.5 / \mathrm{t}$ \\
\hline Processing & & $2.8 / \mathrm{t}$ \\
\hline Variables & & - \\
\hline Maintenance & & $15,000 /$ month \\
\hline Environmental Protection and Mine Closure & & $18,200 /$ month \\
\hline Rates & & $1,000 /$ month \\
\hline Administrative expenses Inputs & & $35,300 /$ month \\
\hline Selling Expenses (0.01\% FBA) & & $3,889 /$ month \\
\hline Eventual & & $5,000 /$ month \\
\hline
\end{tabular}

For a proper analysis of the economic feasibility of a project, in addition

to OPEX and CAPEX, some indicators are essential, such as the Internal Rate of Return (IRR) and Net Present Value (NPV) by using the equation (1).

$$
N P V=\text { Initial Investiment }+\sum_{n=0}^{N} \frac{C_{n}}{(1+r)^{n}}=0
$$

Where: $C n$ is the cash flow in $t$;

$t$ is the nth period in time in which the money will be invested in the project

A summary of these calculations is shown in cash flows for scenarios 1 and 3 (Tables 4, 5 and 6). The results obtained (starts in period 1 , when there is effectively the first cash flow);

$N$ is the number of periods t;

in the feasibility analysis demonstrate that only Scenarios 1 and 3 are technically and economically viable. The operation of return.

$r$ is the cost of equity/internal rate

for Scenario 2 is not economically viable because the ore reserve available in this scenario is insufficient to pay the initial 
investment needed and to cover the operational costs. On the other hand, the results obtained for scenarios 1 and 3 show to Table 7 presents a comparison of values be promising, but with some differences. of the financial data for both scenarios.

\begin{tabular}{|c|c|c|c|c|c|c|c|c|c|c|c|}
\hline $\begin{array}{l}\text { Project } \\
\text { Year }\end{array}$ & 0 & 1 & 2 & 3 & 4 & 5 & 6 & 7 & 8 & 9 & 10 \\
\hline Capex & $-7,140$ & & & & & & & $-6,165$ & & & \\
\hline $\begin{array}{l}\text { Annual } \\
\text { Gross } \\
\text { Revenue }\end{array}$ & & 38,880 & 38,880 & 38,880 & 38,880 & 38,880 & 38,880 & 38,880 & 38,880 & 38,880 & 38,880 \\
\hline Tax & & $-9,594$ & $-9,594$ & $-9,594)$ & $-9,594$ & $-9,594$ & $-10,027$ & $-9,594$ & $-9,594$ & $-9,594$ & $-9,594$ \\
\hline Opex & & $-26,329$ & $-26,329$ & $-26,329$ & $-26,329$ & $-26,329$ & $-26,329$ & $-26,329$ & $-26,329$ & $-26,329$ & $-26,329$ \\
\hline $\begin{array}{c}\text { Annual } \\
\text { Net } \\
\text { Revenue }\end{array}$ & & 2,957 & 2,957 & 2,957 & 2,957 & 2,957 & 2,524 & 2,957 & 2,957 & 2,957 & 2,957 \\
\hline $\begin{array}{c}\text { Accu- } \\
\text { mulated } \\
\text { Net }\end{array}$ & $-7,140$ & $-4,183$ & $-1,227$ & 1,730 & 4,686 & 7,643 & 10,167 & 6,958 & 9,915 & 12,871 & 15,828 \\
\hline VA & 464,647 & $-3,638$ & $-1,067$ & 1,504 & 4,075 & 6,646 & 8,840 & 6,051 & 8,621 & 11,192 & 13,763 \\
\hline $\begin{array}{c}\text { Project } \\
\text { Year }\end{array}$ & 11 & 12 & 13 & 14 & 15 & 16 & 17 & 18 & 19 & 20 & 21 \\
\hline Capex & & & & $-6,165$ & & & & & & & $-6,165$ \\
\hline $\begin{array}{c}\text { Annual } \\
\text { Gross } \\
\text { Revenue }\end{array}$ & 38,880 & 38,880 & 38,880 & 38,880 & 38,880 & 38,880 & 38,880 & 38,880 & 38,880 & 38,880 & 38,880 \\
\hline Tax & $-9,594$ & $-10,027$ & $-10,027$ & $-9,594$ & $-9,594$ & $-9,597$ & $-9,597$ & $-9,597$ & $-10,030$ & $-10,030$ & $-9,597$ \\
\hline Opex & $-26,329$ & $-26,329$ & $-26,329$ & $-26,329$ & $-26,329$ & $-26,329$ & 26,329 & $-26,329$ & $-26,329$ & $-26,329$ & $-26,329$ \\
\hline $\begin{array}{c}\text { Annual } \\
\text { Net } \\
\text { Revenue }\end{array}$ & 2,957 & 2,524 & 2,524 & 2,957 & 2,957 & 2,954 & 2,954 & 2,954 & 2,521 & 2,521 & 2,954 \\
\hline $\begin{array}{c}\text { Accu- } \\
\text { mulated } \\
\text { Net }\end{array}$ & 18,784 & 21,308 & 23,832 & 20,623 & 23,580 & 26,534 & 29,488 & 32,443 & 34,964 & 37,485 & 34,275 \\
\hline VA & 16,334 & 18,529 & 20,723 & 17,933 & 20,504 & 23,073 & 25,642 & 28,211 & 30,404 & 32,596 & 29,804 \\
\hline $\begin{array}{c}\text { Project } \\
\text { Year }\end{array}$ & 22 & 23 & 24 & 25 & 26 & 27 & 28 & 29 & 30 & 31 & \\
\hline Capex & & & & & & $-6,165$ & & & & & \\
\hline $\begin{array}{c}\text { Annual } \\
\text { Gross } \\
\text { Revenue }\end{array}$ & 38,880 & 38,880 & 38,880 & 38,880 & 38,880 & 38,880 & 38,880 & 38,880 & 38,880 & 38,880 & \\
\hline Tax & $-9,597$ & $-9,597$ & $-9,597$ & $-9,597$ & $-10,030$ & $-10,030$ & $-9,597$ & $-9,597$ & $-9,597$ & $-9,597$ & \\
\hline Opex & $-26,329$ & $-26,329$ & $-26,329$ & $-26,329$ & $-26,329$ & $-26,329$ & $-26,329$ & $-26,329$ & $-26,329$ & $-26,329$ & \\
\hline $\begin{array}{l}\text { Annual } \\
\text { Net } \\
\text { Revenue }\end{array}$ & 2,954 & 2,954 & 2,954 & 2,954 & 2,521 & 2,521 & 2,954 & 2,954 & 2,954 & 2,954 & \\
\hline $\begin{array}{l}\text { Accu- } \\
\text { mulated } \\
\text { Net }\end{array}$ & 37,229 & 40,183 & 43,137 & 46,092 & 48,613 & 51,134 & 47,924 & 50,878 & 53,832 & 57,286 & \\
\hline VA & 32,373 & 34,942 & 37,511 & 40,080 & 42,272 & 44,465 & 41,673 & 44,242 & 46,810 & 49,814 & \\
\hline $\begin{array}{c}\text { Total } \\
\text { invest- } \\
\text { ment }\end{array}$ & $-31,800$ & & & & & & & & & & \\
\hline
\end{tabular}




\begin{tabular}{|c|c|c|c|}
\hline Project Year & 0 & 1 & 2 \\
\hline Capex & $-6,890$ & & \\
\hline Annual Gross Revenue & & 38,880 & 38,880 \\
\hline Tax & & $-8,417$ & $-8,417$ \\
\hline Opex & & $-38,079$ & 38,079 \\
\hline Annual Net Revenue & & $-7,616$ & $-7,616$ \\
\hline Accumulated Net & $-6,890)$ & $-14,506$ & $-22,122$ \\
\hline VA & $-31,938$ & $-12,700$ & $-19,237$ \\
\hline Total Investment & $-6,890$ & & \\
\hline
\end{tabular}

Table 5

\begin{tabular}{|c|c|c|c|c|c|c|c|c|c|c|c|}
\hline $\begin{array}{c}\text { Project } \\
\text { Year }\end{array}$ & 0 & 1 & 2 & 3 & 4 & 5 & 6 & 7 & 8 & 9 & 10 \\
\hline Capex & $-7,140$ & & & & & & & $-6,165$ & & & \\
\hline $\begin{array}{c}\text { Annual } \\
\text { Gross } \\
\text { Revenue }\end{array}$ & & 38,880 & 38,880 & 38,880 & 38,880 & 38,880 & 38,880 & 38,880 & 38,880 & 38,880 & 38,880 \\
\hline Tax & & $-9,325$ & $-9,325$ & $-9,325$ & $-9,325$ & $-9,325$ & $-9,758$ & $-9,325$ & $-9,325$ & $-9,325)$ & $-9,325$ \\
\hline Opex & & $-27,020$ & $-27,020$ & $-27,020$ & $-27,020$ & $-27,020$ & $-27,020$ & $-27,020$ & $-27,020$ & $-27,020$ & $-27,020$ \\
\hline $\begin{array}{l}\text { Annual } \\
\text { Net Rev- } \\
\text { enue }\end{array}$ & & 2,535 & 2,535 & 2,535 & 2,535 & 2,535 & 2,102 & 2,535 & 2,535 & 2,535 & 2,535 \\
\hline $\begin{array}{c}\text { Accu- } \\
\text { mulated } \\
\text { Net }\end{array}$ & $-6,890$ & $-4,355$ & $-1,820$ & 715 & 3,250 & 5,785 & 7,887 & 4,257 & 6,792 & 9,327 & 11,861 \\
\hline VA & 146,763 & $-3,787$ & $-1,583$ & 622 & 2,826 & 5,030 & 6,858 & 3,701 & 5,906 & 8,110 & 10,314 \\
\hline $\begin{array}{c}\text { Project } \\
\text { Year }\end{array}$ & 11 & 12 & 13 & 14 & 15 & 16 & 17 & & & & \\
\hline Capex & & & & $-6,165$ & & & & & & & \\
\hline $\begin{array}{c}\text { Annual } \\
\text { Gross } \\
\text { Revenue }\end{array}$ & 38,880 & 38,880 & 38,880 & 38,880 & 38,880 & 38,880 & 38,880 & & & & \\
\hline Tax & $-9,325$ & $-9,758$ & $-9,758$ & $-9,325$ & $-9,325$ & $-9,327$ & $-9,327$ & & & & \\
\hline Opex & $-27,020$ & $-27,020$ & $-27,020$ & $-27,020$ & $-27,020$ & 27,020 & $-27,020$ & & & & \\
\hline $\begin{array}{l}\text { Annual } \\
\text { Net Rev- } \\
\text { enue }\end{array}$ & 2,535 & 2,102 & 2,102 & 2,535 & 2,535 & 2,533 & 2,533 & & & & \\
\hline $\begin{array}{c}\text { Accu- } \\
\text { mulated } \\
\text { Net }\end{array}$ & 14,396 & 16,498 & 18,601 & 14,971 & 17,505 & 20,038 & 23,071 & & & & \\
\hline VA & 12,519 & 14,347 & 16,174 & 13,018 & 15,222 & 17,424 & 20,061 & & & & \\
\hline $\begin{array}{c}\text { Total } \\
\text { invest- } \\
\text { ment }\end{array}$ & $-19,220$ & & & & & & & & & & \\
\hline
\end{tabular}

Cash Flow for Scenario 2 (x R $\$ 1,000.00)$

Table 6

Cash Flow for Scenario 3 (x R\$1,000.00) 
Financial Data Comparison

Table 7

Comparasion between Scenarios 1 and 3

Both projects have an IRR above the minimum attractiveness rate, since these values ensure and prove the feasibility of the project. Based on the data, Scenario 1 seems to be more advantageous than Scenario 3, thanks to a real net income and a current value index greater than Scenario 3, in addition to having an inferior return period for the investments. Scenario 1 has a better financial return for the investors in spite

\section{Conclusions}

Mining like any other branch of industry is required for the maintenance of society, since directly or indirectly it provides raw materials for several industrial sectors. But that doesn't mean that environmental issues should be forgotten or put into the background.

Recent modifications in the protection legislation for natural underground cavities divide the opinions of specialists. Taking the miners' viewpoint, these alterations were positive for the sector, for the fact that it adopts well-defined criteria, a little subjective in a certain way, but effective in the determination of how much a cavity can represent a risk for the

\begin{tabular}{c|c|c}
\hline Items & $1^{3 t}$ Scenario & $3^{\text {rd }}$ Scenario \\
\hline Initial Investments & $\mathrm{R} \$ 7,090,000.00$ & $\mathrm{R} \$ 6,890,000.00$ \\
\hline Return Period (years) & 2.8 & $15.00 \%$ \\
\hline $\begin{array}{c}\text { Minimum Attractiveness Rate } \\
\text { (aa) }\end{array}$ & $15.00 \%$ & $21.75 \%$ \\
\hline Internal Rate of Return & $30.42 \%$ & $\mathrm{R} \$ 2,099,768.61$ \\
\hline Real Net Income & $\mathrm{R} \$ 2,521,582.89$ & $\mathrm{R} \$ 97,099,293.06$ \\
\hline Current Value & $\mathrm{R} \$ 365,456,476.17$ & $\mathrm{R} \$ 8,583,233.32$ \\
\hline Present Net Value & $\mathrm{R} \$ 35,197,730.38$ & $5.40 \%$ \\
\hline Simple Profitability & $6.49 \%$ & $\mathrm{R} \$ 19,220,000.00$ \\
\hline Total Investments & $\mathrm{R} \$ 31,800,000.00$ & 5.05 \\
\hline IVA & 11.46 & 2 \\
\hline
\end{tabular}

of having a greater initial investment. In terms of decision-making, Scenario 1 seems to be the better choice for shareholders and for the local community, due to its high profitability and longevity of the operation, approximately 31 years.

The proposal for Scenario 3 should not be immediately dismissed. It can be used as an alternative plan, if in the worst case-scenario, the permission for the realization of suppression of cavi- ties necessary for the mine development cannot be granted from the responsible environmental agency, or if the compensatory measures required have values higher than those expected for the project. In case of no permission is granted for the suppression of cavities, or in case the compensatory measures required imply a high implantation cost, Scenario 3 also becomes attractive and competes with Scenario 1. enterprise development.

If during the environmental licensing process, natural cavities are found that could affect negatively the development of a mining project, researches on the reduction of the protection radius, defined by law, will be paramount. Such studies should involve the physical stability of cavities, as well as biospeleological conditions. Conducting preliminary researches about the existence of cavities should be done using the database available on the Brazilian Speleological Society (SBE) and of National Cavities Conservation and Research Centre (CECAV) sites.
It is recommended, when possible, to conduct a recognition survey of the speleological potential of the chosen area. Studying the relationship of natural cavities with mining projects, it is especially important in the current context for carbonate rocks, and more recently, iron ore deposits due to environmental issues, the maintenance of economic growth, and the increasing need for raw material from ore goods. Several factors must be analyzed to determine whether a project is possible or not, and one of these factors is the existence of cavities with important attributes.

\section{References}

AQUINO, B. M. I. Análise da viabilidade econômica de um projeto de lavra em razão da proximidade com cavidades naturais subterrâneas. Ouro Preto: Escola de Minas, Universidade Federal de Ouro Preto, 2014. (Dissertação de Mestrado em Engenharia Mineral).

BRASIL. Código Tributário Nacional. Lei n 5.172, de 25/10/1966. Disponível em: $<$ http://www.receita.fazenda.gov.br>. Acesso em 15/05/2011.

BRASIL. Instituto Brasileiro do Meio Ambiente e dos Recursos Naturais Renováveis, Resolução IBAMA $n^{\circ} 887,15$ junho 1990, Delibera sobre o patrimônio espeleoló- 
gico nacional e delimita a área de influência das cavidades naturais. Diário Oficial da União, no 117, Seção I, Pág. 11844. de 20 jul 1990.

BRASIL. Ministério do Meio Ambiente. Resolução CONAMA n 347, 10 setembro 2004, Dispõe sobre a proteção do patrimônio espeleológico. Diário Oficial da União, no 176, Seção 1, páginas- 54-55 de 13 de set. de 2004.

BRASIL. Ministério do Meio Ambiente.Instrução Normativa IN $n^{\circ}$ 02, 20 agosto 2009, Dispõe sobre a proteção do patrimônio espeleológico.

BRASIL. Presidência da República, Casa Civil, Subchefia para Assuntos Jurídicos. Decreto $n^{\circ} 6.640,7$ novembro 2008 , Dá nova redação aos arts. $1^{\circ}, 2^{\circ}, 3^{\circ}, 4^{\circ}$ e $5^{\circ} \mathrm{e}$ acrescenta os arts. 5-A e 5-B ao Decreto no 99.556, de $1^{\circ}$ de outubro de 1990, que dispõe sobre a proteção das cavidades naturais subterrâneas existentes no território nacional.

CURI, A. Minas a céu aberto - planejamento e lavra. Ed. Oficina de Textos, 2014

FORD, D. Characteristics of dissolutional cave systems in carbonate rocks. In: James, N. P., CHOQUETTE, P. W. (Eds.) Paleokarst. p. 25-57, 1988. (part 1).

HARTMAN, H. L. (Ed.).ditor in SME Mining Engineering Handbook. $2 \mathrm{~d}$ Ed. Littleton, CO: Society for Mining, Metallurgy and Exploration, 1992.

HARTMAN, H. L., MUTMANSKY, J. M. Introductory Mining Engineering. (2.ed.). Canada: Ins. Wiley - Interscience publication, 2002.

HUSTRULID, W., KUCHTA M. Open pit mine planning \& design. (2. ed.). 1979 . p. 379 , (v.1 - Fundamentals).

POULSON, T. L.; WHITE, W. B. The Cave Environment. Science, p. 971-981, September 1969.

Received: 02 June 2014 - Accepted: 21 July 2015. 